\title{
Arboreal foraging and ambush by grass snakes Natrix natrix on European treefrogs Hyla arborea
}

\author{
MIKOŁAJ KACZMARSKI \\ Institute of Zoology, Poznań University of Life Sciences, Wojska Polskiego 71c, 60-625 Poznań, Poland \\ Author e-mail: traszka.com@gmail.com
}

n 2011 and 2012, I observed foraging and the use of arboreal ambush sites by grass snakes (Natrix natrix) in a melaphyre quarry in Tłumaczów (SW Poland; 50 33'10" N, 16 25'56" E; $350 \mathrm{~m}$ a.s.l.) (Fig. 1A). The bottom of the quarry contained a pond (ca 1 ha in area) and around the pond shoreline willow shrubs up to $3 \mathrm{~m}$ high were growing partly out of the water in clusters (Fig. 1A). As the only tall objects at the edge of the pond, these shrubs were being used by European treefrogs (Hyla arborea) as diurnal hiding places from which they began to vocalise after dark. There were birch (Betula spp.) and the Eurasian aspen (Populus tremula) near the pond but neither $N$. natrix nor $H$. arborea were observed on them.

On my first visit to the quarry, on 28th June 2011, several juvenile snakes (not exceeding 40 to $50 \mathrm{~cm}$ ) foraged, ambushed, and swallowed adult tree frogs which had been resting on the branches of willows (Salix spp.) at heights ranging from 0.5 to $2 \mathrm{~m}$.

More detailed studies were undertaken in 2012. From 21 March to 29th April 2012, using drift fences, 71 specimens of $H$. arborea, all of them male, were caught. Also present at the site was a large populations of newts - the Alpine newt Ichthyosaura alpestris, the smooth newt Lissotriton vulgaris, the great crested newt Triturus cristatus (all newts together totalling about 3000 adults) - and a breeding population of the common toad Bufo bufo (no more than 100 adults) (Kaczmarski et al., unpublished data). Three further visits to the site (18th May, 19th May \& 23rd June 2012) where made which allowed further observation on the grass snakes and treefrogs. During the day and on warm nights, grass snake adults and juveniles were observed regularly searching for
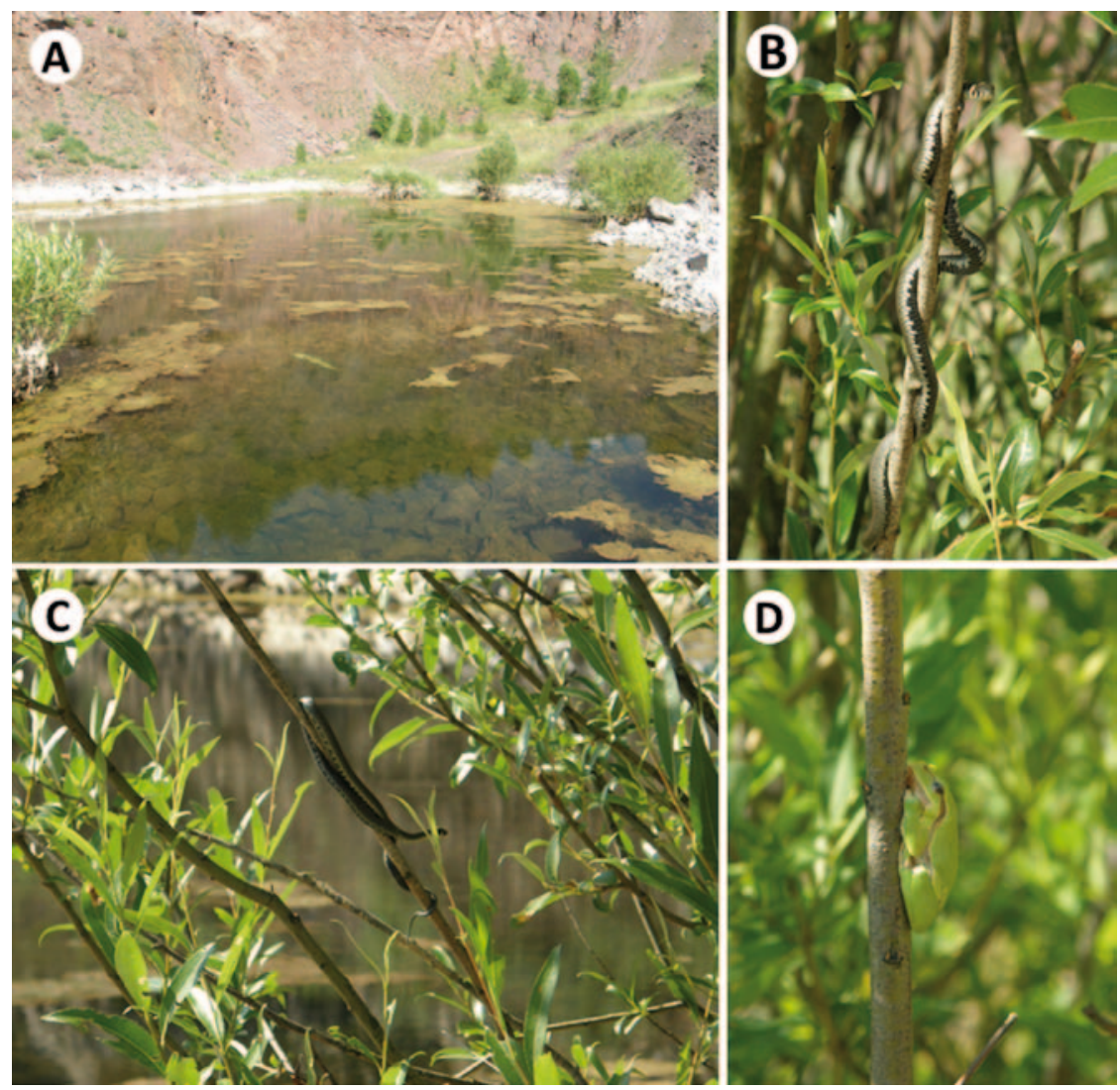

Figure 1. A. Study site in Tłumaczów quarry (Poland) 28 June 2011, B. \& C. Ambush by grass snakes (Natrix natrix), D. European treefrog (Hyla arborea) on the branches of a willow Salix spp. 
amphibians and consuming newts near the pond and the drift fences. However, grass snakes were observed on shrubs only after the start of the $H$. arborea mating season, i.e. after 20 April. Grass snakes were often observed on branches as high as $2 \mathrm{~m}$ above the ground, either actively looking for resting $H$. arborea or remaining in an ambush position (Fig. 1B \& C). All these grass snakes were both timid and vigilant and after detection by an observer moved rapidly along the branches and sometimes directly into the water. Consequently, I was unable to photograph the moment when these snakes swallowed treefrogs. Most of these grass snakes were approximately $40-50 \mathrm{~cm}$ in length, and thus should be considered juveniles or young males. Adult females and males were mainly observed foraging among boulders and stones, but never on willow branches.

The grass snake is a generalist predator, feeding largely on various amphibians and, much less often, on other vertebrates (Gregory \& Isaac, 2004) or invertebrates (Consul, Eger \& Kwet, 2009). Treefrog species (Hyla spp.) have been reported relatively rarely as prey for $N$. natrix but the Sardinian grass snakes (Natrix natrix cetti) is reported as an active hunter in water with the adults and tadpoles of $\mathrm{Hyla}$ sarda as their main prey (Capula, Rugiero \& Luiselli, 1994). There are previous reports of $N$. natrix climbing, where the authors speculate that this enabled the snakes to warm up in the sun and/or search for prey (Bringsøe \& Aastrup, 2017). However, the current report appears to be the first description of several relatively small specimens of $N$. natrix regularly hunting adult $H$. arborea on branches and displaying an ability to balance on thin, flexible willow branches when searching for food.

\section{ACKNOWLEDGEMENTS}

I am grateful to everyone involved in the fieldwork in the Tłumaczów quarry (in alphabetical order: Katarzyna Jankowiak, Jan M. Kaczmarek, Aleksandra Kolanek, Krzysztof Kolenda, Małgorzata Kruszona, Anna M. Kubicka, Maciej Pabijan, Daria Sołtysiak, Edyta Turniak), Piotr Mruk, Strateg Capital Ltd. for access to the quarry facility, and Anna M. Kubicka for valuable comments and guidance in writing the manuscript.

\section{REFERENCES}

Bringsoe, H. \& Aastrup, H. (2017). Natrix natrix (Linnaeus, 1758) climbing tree to a height of $475 \mathrm{~cm}$. Herpetozoa 29: 212-214

Capula, M., Rugiero, L. \& Luiselli, L. (1994). Ecological observations on the Sardinian grass snake, Natrix natix cetti. Amphibia-Reptilia 15: 221-227.

Consul, A., Eger, S. \& Kwet, A. (2009). The grass snake, Natrix natrix natrix (Squamata: Colubridae), as a predator of the great ramshorn snail, Planorbarius $c$. corneus (Gastropoda: Planorbidae). Salamandra 45: 50-52.

Gregory, P. T. \& Isaac, L. A. (2004). Food habits of the grass snake in southeastern England: is Natrix natrix a generalist predator? Journal of Herpetology 38: 88-95.

Accepted: 30 September 2020 